\title{
The Potential and Application Frequency of Yeast from Tomato and Cogon Grass Leaves to Suppress Powdery Mildew Disease in Tomato
}

\author{
Noor Istifadah ${ }^{1^{*}}$, Nurul Ihsani ${ }^{2}$, dan Sri Hartati ${ }^{1}$ \\ ${ }^{1}$ Department of Plant Pests and Diseases, Agriculture Faculty, Universitas Padjadjaran, Jatinangor, West Java, \\ Indonesia, 45363 \\ ${ }^{2}$ Alumnus of Plant Pests and Diseases Department, Agriculture Faculty, Universitas Padjadjaran, Jatinangor, \\ West Java, Indonesia, 45363 \\ * Corresponding author : n.istifadah@ unpad.ac.id
}

\begin{abstract}
Powdery mildew (Oidium sp.) is important disease in the greenhouse tomato production. One of environmentally-friendly control method of the disease is biological control. Yeast from phyloplane of weeds such as cogon grass are potential as biocontrol agents. This study evaluated the potential of yeast isolated from the leaves of cogon grass and wild tomato to suppress powdery mildew of tomato. The samples were obtained from several areas in Sumedang and Bandung, West Java. The yeast isolates were selected on their abilities in controlling powdery mildew in tomato seedlings. The selected isolates were used for further experiment examining the effects of frequency of yeast application on the disease control. This experiment was arranged in Randomized Complete Block Design with 12 treatments and three replications. The treatments were three yeast isolates, applied once before pathogen inoculation, applied regularly every week or two weeks, the check and fungicide treatment. The results showed that among 13 yeast isolates obtained there were three isolates that suppressed the development of powdery mildew disease by $61.0 \%-68.6 \%$. In further experiment, relatively highest disease reduction $(58,6 \%)$ was showed in the application of yeast isolate from wild tomato leaves (TB1 isolate) every week.
\end{abstract}

Keywords : biological control, phyloplane, Oidium sp., wild tomato

\section{ABSTRAK}

Potensi dan Frekuensi Aplikasi Khamir Asal Daun Tomat dan Alang-alang untuk Menekan Penyakit Embun Tepung pada Tanaman Tomat

Penyakit embun tepung (Oidium sp.) merupakan salah satu penyakit penting pada tanaman tomat, terutama yang dibudidayakan di rumah kaca. Salah satu cara pengendalian yang ramah lingkungan adalah dengan pengendalian biologi. Khamir dari filoplan tumbuhan liar atau gulma seperti alang-alang berpotensi sebagai agens pengendali biologi penyakit tanaman. Penelitian ini bertujuan untuk mengevaluasi kemampuan khamir yang diisolasi dari daun tomat liar dan alangalang untuk menekan penyakit embun tepung pada tanaman tomat. Daun sampel diperoleh dari beberapa lokasi di daerah Sumedang dan Bandung, Jawa Barat. Isolat khamir yang diperoleh diseleksi kemampuannya untuk menekan penyakit embun tepung pada bibit tomat. Beberapa isolat yang dapat menekan penyakit relatif lebih baik diuji lebih lanjut untuk mendapatkan interval aplikasi yang menghasilkan efek pengendalian yang paling baik. Percobaan lanjutan menggunakan Rancangan Acak Kelompok dengan perlakuan isolat khamir dengan interval aplikasi hanya sekali sebelum inokulasi patogen, aplikasi secara reguler seminggu atau dua minggu sekali, kontrol dan fungisida. Hasil percobaan menunjukkan bahwa dari 13 isolat khamir yang diperoleh terdapat tiga isolat yang dapat menekan perkembangan penyakit embun tepung sebesar $61,0 \%$ - 68,6\%. Pada uji lanjutan, perlakuan yang menghasilkan penekanan terhadap penyakit embun tepung relatif paling baik $(58,6 \%)$ yaitu perlakuan dengan isolat khamir asal daun tomat (isolat TB1) dengan interval penyemprotan seminggu sekali.

Kata Kunci : pengendalian biologi, filoplan, Oidium sp., tomat liar

\section{PENDAHULUAN}

Tomat merupakan komoditas hortikultura yang dapat dianggap sebagai sayur maupun buah. Salah satu kendala dalam budidaya tanaman tomat terutama yang di rumah kaca atau rumah plastik adalah penyakit embun tepung. Di Indonesia, penyakit ini disebabkan oleh jamur Oidium sp. (Semangun, 2007). Patogen ini dapat menginfeksi berbagai bagian dari tanaman di atas tanah seperti daun, batang, ranting dan tangkai buah. Penyakit dapat dikenali melalui gejalanya yang berupa bercak-bercak putih seperti tepung. Jaringan yang terinfeksi menjadi kekuningan dan akhirnya mengering (Douglas, 2003; Semangun,
2007). Penyakit berkembang baik pada lingkungan yang lembab, namun demikian cuaca yang kering dan angin dapat membantu penyebaran konidianya (Douglas, 2003).

Penyakit ini biasa dikendalikan dengan menggunakan pestisida sintetik. Padahal, penggunaan petisida sintetik ini apabila dilakukan secara terus menerus dapat menyebabkan berbagai dampak negatif antara lain timbulnya resistensi patogen dan akumulasi residu pada produk yaitu pada buah tomatnya. Guna menghindari hal ini, maka perlu dikembangkan cara pengendalian yang ramah lingkungan di antaranya adalah pengendalian secara biologi. 
Mikrob yang dapat digunakan sebagai agens pengendali hayati penyakit tanaman adalah khamir (yeast) yaitu jamur yang bersel tunggal. Khamir merupakan kelompok mikrob yang banyak ditemukan pada permukaan daun (Andrew \& Buck, 2002; Inacio et al., 2010). Penggunaan khamir untuk pengendalian penyakit tular udara dan pasca panen sudah banyak dikaji (misalnya: Zamir et al. 2003; Kalogiannis et al., 2006; Hartati et al., 2015; Pretscher et al., 2018). Mekanisme penghambatan patogen oleh khamir dapat berupa adanya kompetisi ruang tumbuh dan nutrisi, produksi senyawa antimikrob, enzim pendegradasi dinding sel patogen (Avis et al., 2002; Gafni et al., 2015; Pretscher et al. 2018) atau adanya hiperparasitisme (Gafni et al., 2015; Hartati et al., 2015).

Mikrob antagonis dapat diisolasi dari habitat di mana patogen sasarannya berada. Untuk pengendalian penyakit tular udara, patogen dapat diisolasi dari daun atau filoplan. Mengingat kebanyakan tanaman budidaya seringkali disemprot pestisida, agar mendapatkan mikrob yang lebih banyak dan bervariasi maka mikrob dapat diisolasi dari tumbuhan yang hidup liar atau gulma. Alang-alang merupakan gulma yang dapat tumbuh di berbagai tempat dan sangat tahan terhadap kondisi lingkungan yang ekstrim misalnya kekeringan dan tanah yang tandus. Mikrob yang berasosiasi dengan alang-alang kemungkinan besar juga dapat beradaptasi terhadap lingkungan yang kurang mendukung.

Mikrob yang berasosiasi dengan alang-alang telah diketahui kemampuannya sebagai pengendali penyakit tanaman. Istifadah \& Cahyani (2007) juga telah menemukan jamur endofit dari akar alang-alang yang dapat mengolonisasi perakaran cabai dan efektif dalam menekan penyakit rebah semai pada cabai. Bakteri dan jamur endofit dari akar alang-alang juga telah dilaporkan dapat menekan penyakit akar gada pada kubis (Istifadah \& Suganda, 2010). Istifadah \& Gumelar (2017) telah mengisolasi bakteri endofit dari daun tomat liar dan daun alang-alang guna mendapatkan isolat yang dapat menekan penyakit embun tepung. Namun demikian, ternyata isolat bakteri endofit tersebut kurang efektif menekan penyakit embun tepung. Oleh karena itu dilakukan penelitian yang mengevaluasi potensi jenis mikrob yang lain yaitu khamir yang berasal dari daun alangalang dan tomat liar, untuk mengendalikan penyakit embun tepung pada tomat. Tulisan ini mendiskusikan hasil penelitian tersebut, termasuk interval aplikasi isolat khamir yang dapat menghasilkan tingkat penekanan terbaik terhadap penyakit embun tepung pada tomat.

\section{BAHAN DAN METODE}

\section{Isolasi khamir dari daun alang-alang dan tomat liar}

Khamir diisolasi dari daun alang-alang dan tomat yang tumbuh liar. Sampel tumbuhan diperoleh dari beberapa lokasi yaitu daerah Jatinangor dan Tanjungsari (Kabupten Sumedang), daerah Ujung Berung (Kotamadya Bandung), dan Banjaran (Kabupaten Bandung). Sampel daun ditimbang sebanyak $5 \mathrm{~g}$ kemudian dibersihkan dengan menggunakan air mengalir. Daun kemudian dipotongpotong sebesar kira-kira $0,5 \mathrm{~cm}^{2}$ dan dimasukkan ke dalam air steril yang telah diberi surfactant, Tween 80 (10 $\mu \mathrm{l}$ per $100 \mathrm{ml}$ air) sebanyak $100 \mathrm{ml}$. Daun yang telah terendam air kemudian dihomogenkan dengan vortex stirrer selama 3 menit. Setelah dibuat pengenceran berseri, khamir diisolasi dari suspensi yang berasal dari pengenceran $10^{-3}, 10^{-4}$ dan $10^{-5}$. Media yang digunakan adalah media Potato Dekstrose Agar dan Malt Ekstrak Agar. Khamir dengan karakteristik koloni yang berbeda dicek dengan menggunakan mikroskop dan dimurnikan.

\section{Seleksi isolat khamir untuk menekan penyakit embun tepung}

Aplikasi khamir dilakukan dengan menggunakan suspensi sel khamir dalam air steril yang mengandung sukrosa $(0,05 \%)$. Suspensi tersebut diaplikasikan dengan cara disemprotkan pada daun bibit tomat yang berumur 14 hari sampai semua daun terlihat basah. Untuk kontrol, bibit tomat disemprot dengan air steril. Bibit tomat yang telah diberi perlakuan ditutup dengan plastik selama 48 jam untuk menjaga kelembaban tanaman.

Inokulasi patogen dilakukan dua hari setelah aplikasi khamir. Patogen diinokulasikan pada daun tengah dari daun majemuk dengan cara menempelkan potongan daun bergejala (dengan ukuran $0,5 \times 0,5$ $\mathrm{cm}^{2}$ ) dan direkatkan menggunakan cling wrap. Inokulum dan cling wrap dilepas setelah 2 hari kemudian dilakukan pengamatan terhadap kemunculan gejala penyakit.

Pengamatan intensitas penyakit dilakukan setiap tiga hari sekali. Intensitas penyakit dihitung berdasarkan rumus $\mathrm{I}=\left[\left(\sum(\mathrm{n} * \mathrm{v})\right) /(\mathrm{N} * \mathrm{~V})\right] x 100 \%$ dimana $\mathrm{v}$ : nilai skor gejala penyakit, $\mathrm{n}$ : jumlah daun dengan skor tersebut, $\mathrm{N}$ : jumlah daun yang diamati, dan V: skor tertinggi yang digunakan. Adapun skor gejala yang digunakan adalah skor yang dimodifikasi dari Horsfall Barret yaitu 0: tidak bergejala, 1:persentase gejala penyakit pada daun sebesar $0<\mathrm{x} \leq$ $12 \% ; 2$ : persentase gejala penyakit pada daun sebesar $12 \%<\mathrm{x} \leq 25 \%$; 3: persentase gejala penyakit pada daun sebesar $25 \%<\mathrm{x} \leq 50 \%$; 4: persentase gejala penyakit pada daun sebesar $50 \%<\mathrm{x} \leq 75 \%$; 5 : persentase gejala penyakit pada daun sebesar $75 \%<x$ $\leq 100 \%$. Data intensitas yang diperoleh digunakan untuk penghitungan total perkembangan penyakit yang didasarkan pada rumus Area Under Disease Progress/AUDPC (Campbell \& Madden, 1990).

Uji frekuensi aplikasi Yeast asal Daun Tomat dan Alang-alang untuk Menekan Penyakit Embun Tepung pada Tanaman Tomat 
Tiga isolat terbaik hasil seleksi digunakan untuk pengujian berikutnya. Percobaan menggunakan Rancangan Acak Kelompok dengan 12 perlakuan dan tiga ulangan. Perlakuan yang diuji adalah kontrol (tanpa perlakuan), penyemprotan dengan fungisida (berbahan aktif propineb) seminggu sekali serta perlakuan frekeuensi aplikasi khamir yaitu setiap 1, 2 dan 4 minggu sekali dengan menggunakan tiga isolat khamir hasil seleksi.

Bibit tomat yang berumur tiga minggu dipindahtanamkan ke dalam polybag yang berisi $2 \mathrm{~kg}$ media tanam. Media yang digunakan tanah dan pupuk kandang kambing 3:1 (v/v) yang telah dipasteurisasi (dikukus selama 4 jam). Satu minggu setelah pindah tanam, dilakukan aplikasi semua perlakuan termasuk kontrol dan pembanding. Inokulasi patogen dilakukan dengan cara seperti pada percobaan tahap seleksi. Frekuensi aplikasi khamir dilakukan 1, 2, atau 4 minggu sekali sesuai dengan perlakuannya. Intensitas penyakit diamati setiap tiga hari sekali. Data yang diperoleh digunakan untuk penghitungan AUDPC.

Data yang diperoleh dianalisis secara statistik dengan menggunakan program SPSS 20. Normalitas dari data dicek terlebih dahulu dan apabila diperlukan dilakukan transformasi data. Perbedaan antar perlakuan diuji lebih lanjut dengan menggunakan Tuckey's HSD pada taraf 5\%.

\section{HASIL DAN PEMBAHASAN}

Kemampuan isolat khamir untuk menekan penyakit embun tepung pada tanaman tomat
Isolasi khamir dari daun tanaman tomat yang tumbuh liar dan rumput alang-alang beberapa lokasi menghasilkan 13 isolat yang terdiri dari 5 isolat dari sampel daerah Jatinangor, 2 isolat dari Tanjungsari (Sumedang), 2 isolat dari daerah Ujung Berung (Kotamadya Bandung, dan 4 isolat dari sampel daerah Banjaran (Kabupaten Bandung). Mengingat koloninya yang mirip dengan koloni bakteri, maka untuk meyakinkan bhawa itu khamir dilakukan pengamatan secara mikroskopis. Pada masing-masing lokasi, walaupun jumlah koloninya cukup banyak namun karena karakteristiknya sama sehingga yg dimurnikan adalah perwakilan isolat dengan karakteristik koloni yang berbeda. Isolat yang berasal dari daun tomat diberi kode $\mathrm{T}$, sedangkan isolat dari daun alang-alang diberi kode A. Dari 13 isolat, diperoleh tujuh isolat dari daun alang-alang dan enam isolat dari daun tanaman tomat liar.

Hasil pengujian terhadap isolat khamir yang diperoleh menunjukkan bahwa isolat-isolat tersebut dapat menekan penyakit embun tepung pada tomat sebesar 42,3\% - 68,6\% (Tabel 1). Isolat khamir yang diaplikasikan sebelum inokulasi patogen ternyata dapat menghambat kemunculan dan perkembangan gejala penyakit embun tepung. Pada kontrol kemunculan gejala penyakit embun tepung terjadi pada 3 hari setelah inokulasi, sedangkan pada perlakuan dengan khamir gejala baru muncul 4 sampai 6 hari setelah infeksi. Hal ini menunjukkan bahwa keberadaan khamir pada daun dapat melindungi daun terhadap infeksi patogen.

Tabel 1. Pengaruh isolat khamir terhadap penyakit embun tepung (Oidium sp.) pada tanaan tomat (pada tahap seleksi)

\begin{tabular}{lccc}
\hline Perlakuan & Masa Inkubasi (hari) & AUDPC & Penghambatan (\%) \\
\hline Isolat TJ & 4 & 369 & 42,3 \\
Isolat AJ1 & 5 & 249 & 61,0 \\
Isolat AJ2 & 5 & 320 & 50,0 \\
Isolat AJ3 & 4 & 220 & 65,6 \\
Isolat AJ4 & 4 & 278 & 56,5 \\
Isolat TB1 & 5 & 201 & 68,6 \\
Isolat TB2 & 5 & 291 & 54,5 \\
Isolat TBj1 & 4 & 343 & 46,3 \\
Isolat TBj2 & 4 & 299 & 53,2 \\
Isolat TBj3 & 6 & 323 & 49,5 \\
Isolat ABj & 4 & 367 & 42,6 \\
Isolat ATs1 & 5 & 286 & 55,2 \\
Isolat ATs2 & 4 & 325 & 49,1 \\
Kontrol & 3 & 639 & - \\
\hline
\end{tabular}


Kemampuan khamir untuk menekan penyakit embun tepung telah dilaporkan. Beberapa spesies khamir seperti Pseudozyma flocculosa (Avis \& Belanger, 2001; Hammami et al., 2011) dan Pseudozyma aphidis (Gafni et al., 2015) dapat menekan penyakit embun tepung pada tanaman Cucurbitaceae. Jacob et al (2007) menemukan empat isolat khamir yang dapat menekan penyakit embun tepung pada tomat yang disebabkan Oidium neolycopersici sebesar 37,6-82,2\%. Punlerdmatee et al. (2017) juga mendapatkan empat isolat khamir dari daun dahlia yang dapat menekan perkecambahan konidia patogen sampai $100 \%$ dan menekan penyakit embun tepung pada dahlia sebesar 88,4-100\%.

Kemampuan khamir dalam menekan jamur penyebab embun tepung dapat melalui beberapa mekanisme diantaranya adalah produksi metabolit sekunder yang dapat menghambat perkecambahan konidia patogen penyebab embun tepung (Gafni et al., 2015; Punlerdmatee et al., 2017). Khamir seperti Pseudozyma spp. dapat pula menghasilkan ekstraselular fatty acid yang dapat menyebabkan disintegrasi pada membran dan isi sel dari jamur penyebab embun tepung. Selain itu, khamir juga dapat sebagai ektoparasit pada hifa dan konidia patogen (Gafni et al., 2015). Kemampuan khamir dalam mengolonisasi permukaan daun juga memungkinkan mereka untuk berkompetisi dengan jamur penyebab embun tepung yang perkembangannya juga pada permukaan daun (Gafni et al., 2015; Punlerdmatee et al., 2017).
Pada tahap seleksi ini, kemampuan penekanan khamir terhadap penyakit mencapai $68,6 \%$ walaupun baru diaplikasikan sekali saja sebagai tindakan preventif sebelum adanya patogen. Kemampuan ini diharapkan dapat meningkat apabila aplikasinya dilakukan beberapa kali. Oleh karena itu dilakukan pengujian lebih lanjut mengenai frekuensi aplikasi. Isolat-isolat khamir yang digunakan pada percobaan lanjutan tersebut adalah tiga isolat yang dapat menekan penyakit lebih dari $60 \%$ yaitu dua isolat dari daun alang-alang (AJ1 dan AJ3) serta satu isolat dari daun tomat (TB 1).

\section{Pengaruh frekuensi aplikasi terhadap kemampuan khamir dalam menekan penyakit embun tepung}

Pada percobaan lanjutan, aplikasi tiga isolat khamir yang diuji dapat menekan perkembangan penyakit embun tepung pada tanaman tomat. Pada tanaman kontrol, gejala penyakit mulai muncul pada 2 hari setelah inokulasi, sedangkan pada perlakuan dengan khamir gejala baru muncul 4-5 hari setelah inokulasi patogen. Sampai 12 hari setelah inokulasi patogen, intensitas penyakit embun tepung pada berbagai perlakuan masih relatif rendah yaitu antara $16,7-22,7 \%$. Namun demikian mulai pengamatan 15 hari setelah inokulasi perkembangan penyakit pada tanaman yang diberi perlakuan dengan isolat khamir mulai terhambat dibandingkan dengan perkembangan penyakit pada daun tanaman kontrol yang begitu pesat (Gambar 1).

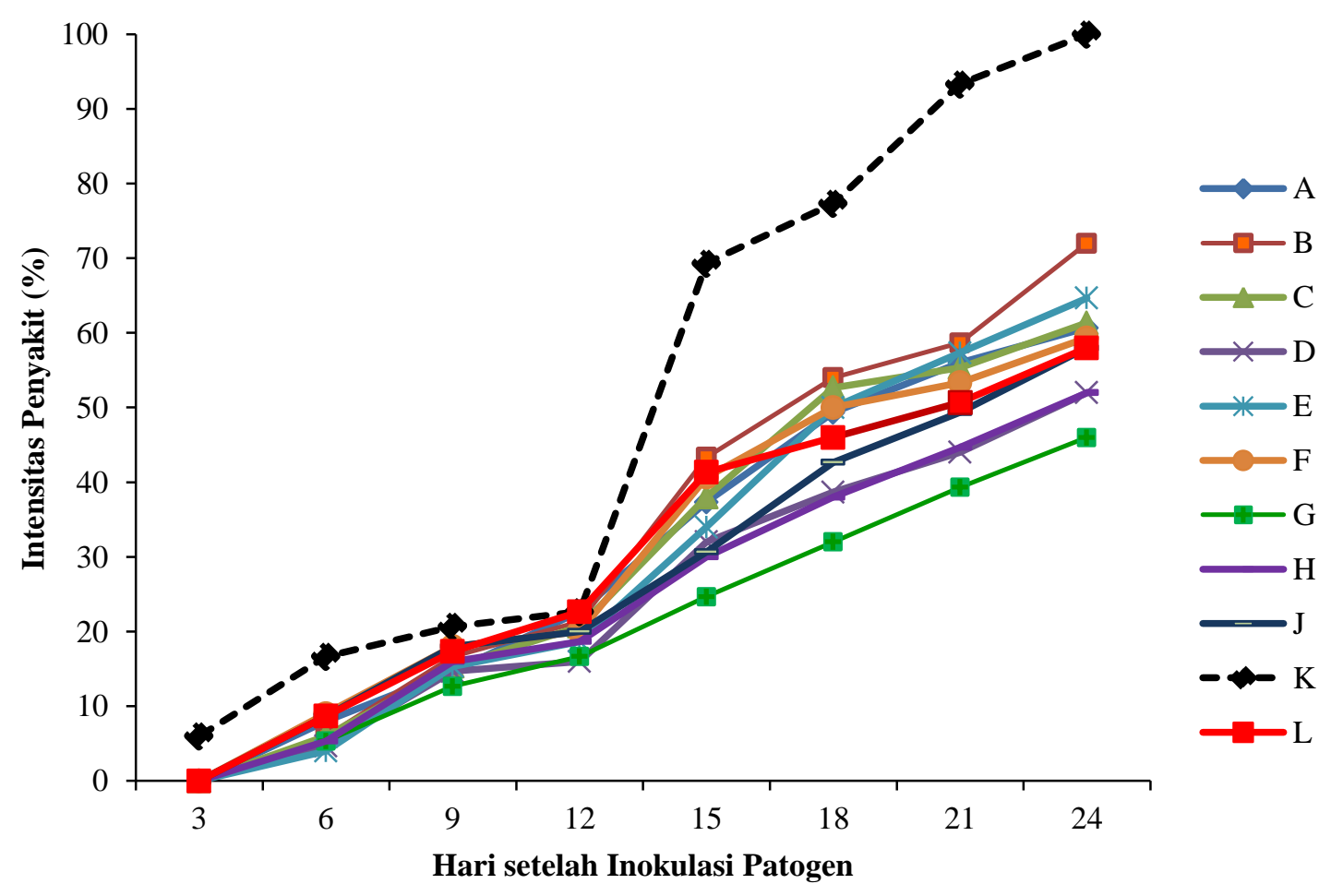

Gambar 1. Perkembangan penyakit embun tepung pada berbagai perlakuan (pada uji lanjutan) 
Rendahnya perkembangan penyakit yang terjadi pada semua perlakuan di awal percobaan kemungkinan karena khamir maupun jamur patogen sama-sama baru beradaptasi dan mulai mengolonisasi permukaan daun tomat. Namun demikian, penghambatan perkembangan penyakit yang terjadi sejak 15 hari setelah inokulasi patogen, pada daun tomat yang diberi perlakuan khamir, diduga karena khamir yang diaplikasikan sudah mulai mengolonisasi permukaan daun dengan baik sehingga efek antagonisme juga sudah mulai terlihat.

Berdasarkan perhitungan AUDPC yang menggambarkan total perkembangan penyakit selama pengamatan, perlakuan dengan khamir dapat menekan penyakit embun tepung sebesar 36,4-58,6\%. Tingkat penekanan penyakit yang dihasilkan oleh ketiga isolat khamir ini sebenarnya relatif lebih rendah dibandingkan dengan tingkat penekanan mereka pada uji seleksi yang mencapai 61,0-68,6\%. Perbedaan tingkat penekanan ini terlihat pada isolat AJ1. Pada tahap seleksi isolat ini dapat menekan penyakit sebesar $61,0 \%$, namun pada tahap percobaan lanjutan, dengan cara aplikasi yang sama, isolat ini hanya dapat menekan penyakit sebesar $36,4 \%$. Perbedaan tingkat kemampuan pada agens biokontrol ini kemungkinan karena perbedaan pada kondisi lingkungan pada saat percobaan yang berpengaruh pada kemampuan kolonisasi khamir pada permukaan daun. Dik et al. (1998) menyatakan bahwa mikroklimat atau lingkungan di sekitar pertanaman serta di dalam greenhouse dapat mempengaruhi efikasi dari agens biocontrol dalam mengendalikan penyakit. Selain itu, pada percobaan lanjutan perkembangan penyakit embun tepung memang lebih pesat sehingga pengendaliannya juga lebih sulit. Jacob et al, (2007) juga melaporkan bahwa tingkat keparahan atau kecepatan perkembangan penyakit berpengaruh terhadap efikasi pengendalian khamir. Pada tekanan penyakit yang tinggi maka tingkat keberhasilan agens biocontrol dalam mengendalikan penyakit juga relatif lebih rendah.

Pada percobaan ini, frekuensi aplikasi ternyata tidak secara nyata berpengaruh terhadap efek penekanan khamir terhadap penyakit embun tepung. Walaupun ada kecenderungan bahwa aplikasi khamir seminggu sekali relatif lebih baik daripada yang diaplikasikan hanya sekali saja, namun demikian secara statistik intensitas penyakit pada perlakuan tersebut tidak berbeda secara nyata (Tabel 2). Almqvist (2012) juga menemukan bahwa pada agens biocontrol tertentu, aplikasi agens biocontrol tersebut baik sebelum (tindakan prefentif) ataupun setelah adanya patogen (kuratif) dapat menghasilkan efek pengendalian yang sama.

Tabel 2. Pengaruh frekuensi aplikasi isolat khamir terhadap penyakit embun tepung (Oidium sp.) pada tanaan tomat (pada uji lanjutan)

\begin{tabular}{|c|c|c|c|}
\hline Perlakuan & Masa Inkubasi (hari) & $\begin{array}{c}\text { Nilai } \\
\text { AUDPC }\end{array}$ & $\begin{array}{c}\text { Penghambatan } \\
(\%)\end{array}$ \\
\hline A: Isolat AJ1-interval penyemprotan seminggu sekali & 4 & $655.0 \mathrm{~b}$ & 41.2 \\
\hline B: Isolat AJ1-interval penyemprotan dua minggu sekali & 5 & $656.0 \mathrm{~b}$ & 41.1 \\
\hline C: Isolat AJ1-aplikasi sebelum inokulasi patogen & 5 & $708.0 \mathrm{~b}$ & 36.4 \\
\hline D: Isolat AJ3-interval penyemprotan seminggu sekali & 5 & $528.0 \mathrm{ab}$ & 52.6 \\
\hline E: Isolat AJ3- interval penyemprotan dua minggu sekali & 5 & $635.0 \mathrm{ab}$ & 42.9 \\
\hline F: Isolat AJ3-aplikasi sebelum inokulasi patogen & 4 & $662.0 \mathrm{~b}$ & 40.5 \\
\hline G: Isolat TB1- interval penyemprotan seminggu sekali & 5 & $461.0 \mathrm{a}$ & 58.6 \\
\hline $\mathrm{H}$ : Isolat TB1-interval penyemprotan dua minggu sekali & 5 & $536.0 \mathrm{ab}$ & 51.8 \\
\hline I: Isolat TB1-aplikasi sebelum inokulasi patogen & 5 & $595.0 \mathrm{ab}$ & 46.5 \\
\hline J: Kontrol (tanpa perlakuan ) & 2 & $1113.0 \mathrm{c}$ & 0.0 \\
\hline K: Kontrol (air steril +Tween $80 \%$ ) & 2 & $1059.0 \mathrm{c}$ & 4.9 \\
\hline L: Fungisida (Propineb 70\%) & 5 & $647.0 \mathrm{ab}$ & 41.9 \\
\hline
\end{tabular}

Keterangan : angka dalam kolom yang diikuti dengan huruf sama berarti tidak berbeda nyata menurut Tukey's HSD pada taraf $5 \%$

Aplikasi khamir yang hanya sekali sebelum inokulasi patogen ternyata sudah dapat menghambat perkembangan penyakit embun tepung. Hal ini mengindikasikan bahwa pengendalian biologi sebenarnya efeknya dapat secara berkelanjutan karena agens biokontrol dapat berkembang dan memperbanyak diri sehingga penghambatannya terhadap patogen pun dapat berlangsung lama. Aplikasi agens pengendali biologi secara preventif atau prophylactic sebelum adanya patogen merupakan strategi untuk memproteksi tanaman dari infeksi patogen. Almqvist (2012) melaporkan bahwa aplikasi agens biokontrol seminggu sekali sebelum adanya infeksi patogen dapat mengendalikan penyakit embun 
tepung pada mentimun yang cenderung lebih baik daripada aplikasi agens biokontrol seminggu sekali namun dilakukan setelah adanya penyakit (secara kuratif).

Pada penelitian ini, efek pengendalian yang dihasilkan oleh perlakuan dengan penyemprotan fungisida berbahan aktif propineb seminggu sekali hanya dapat menekan penyakit embun tepung sebesar $41,9 \%$. Hal ini mengindikasikan bahwa pestisida tersebut sudah tidak efektif lagi. Pestisida tersebut adalah jenis yang memang sudah biasa digunakan oleh petani selama bertahun-tahun sehingga kemungkinan patogen sudah mulai resisten terhadap bahan aktif tersebut.

Hasil penelitian ini secara keseluruhan menunjukkan bahwa isolat khamir yang diperoleh memberikan efek pengendalian penyakit embun tepung yang masih dalam kategori sedang yaitu sekitar 40-58\%. Aplikasi khamir secara regular seminggu sekali cenderung dapat meningkatkan efek pengendalian dibandingkan dengan aplikasi yang hanya sekali saja secara prefentif. Namun demikian, tingkat pengendalian yang dihasilkan juga masih belum mencapai 70\%. Guna mendapatkan efek pengendalian yang lebih baik, penggunaan agens biokontrol tersebut perlu diintegrasikan dengan cara pengendalian lain yang kompatibel dan saling mendukung misalnya penggunaan air rendaman bahan organik. Air rendaman kompos telah dilaporkan dapat menekan penyakit embun tepung pada tanaman tomat (Segarra et al., 2009) dan melon (Naidu et al., 2012). Penggunaan kedua cara tersebut diharapkan dapat bersifat sinergis atau saling melengkapi sehingga memberikan efek pengendalian yang jauh lebih baik.

\section{SIMPULAN DAN SARAN}

\section{Simpulan}

Isolasi khamir dari daun alang-alang dan tomat liar menghasilkan 13 isolat khamir yaitu tujuh isolat dari daun alang-alang dan enam isolat dari daun tanaman tomat liar. Isolat tersebut dapat menekan perkembangan penyakit embun tepung sebesar 42,3\%-68,6\%. Frekuensi aplikasi tidak berpengaruh secara nyata, namun ada kecenderungan aplikasi seminggu sekali dapat meningkatkan efek pengendalian. Pada uji lanjutan, perlakuan yang menghasilkan penekanan terhadap penyakit embun tepung relatif paling baik $(58,6 \%)$ yaitu perlakuan dengan isolat khamir asal daun tomat (isolat TB1) dengan interval penyemprotan seminggu sekali.

\section{Saran}

Isolat khamir yang paling baik dalam menekan penyakit embun tepung yaitu isolat TB1 perlu diidentifkasi lebih lanjut agar diketahui genus dan spesiesnya. Isolat-isolat khamir yang diperoleh dapat diuji potensinya untuk menekan penyakit tomat yang lainnya.

\section{DAFTAR PUSTAKA}

Almqvist A-N. 2012. Biological control of powdery mildew in greenhouse produced cucumberAn evaluation of two microbiological control agents. Swdes University Agricultural Science. Avaliable on line : https://stud.epsilon.slu.se/5163/1/almqvist_ac 130103.pdf (accessed: November 2018).

Andrews JH, Buck JW (2002) Adhesion of yeasts to leaf surfaces. Pp 53-68 In: Lindow S.E, E.I, Hecht-Poinar, V.J. Elliott (eds): Phyllosphere Microbiology. American Phytopathological Society, St. Paul.

Avis, T.J \& Belanger, R. R. 2002. Mechanisms and means of detection of biocontrol activity of Pseudozyma yeasts against plant-pathogenic fungi. FEMS Yeast Res. 2: 5-8.

Campbell, L.C \& V.L. Madden. 1990. Introduction Plant Disease Epidemiology. John Wiley and Son, USA.

Dik, A.J., M.A. Verhaar, \& R.R. Bélanger. 1998. Comparison of three biological control agents against cucumber powdery mildew (Spaerotheca fuliginea) in semi-commercialscale glasshouse trials. Eur J Plant Pathol. 104: 413-423.

Douglas, S.M. 2003. Powdery mildew of tomato. Department of Plant Pathology and Ecology, The Connecticut Agricultural Experiment Station. New Haven Country.

Gafni A, C.E. Calderon, R. Harris, K. Buxdorf, A. Dafa-Berger, E. Zeilinger-Reichert \& M. Levy. 2015. Biological control of the cucurbit powdery mildew pathogen Podosphaera xanthii by means of the epiphytic fungus Pseudozyma aphidis and parasitism as a mode of action. Front. Plant Sci. 6: 132. doi: 10.3389/fpls.2015.00132.

Hammami,W., C.Q. Castro, W. Remus-Borel, C. Labbe \& R. Belanger, 2011. Ecological basis of the interaction between Pseudozyma flocculosa and powdery mildew fungi. Appl.Environ.Microbiol. 77 : 926-933.

Hartati, S., S. Wiyono, S.H. Hidayat, M.S. Sinaga. 2015. Mode of action of yeast-like fungus Aureobasidium pullulans in controlling anthracnose of postharvest chili. International Journal of Sciences: Basic and Applied Research. 20: 253-263.

Inacio, J., W. Ludwig, I. Spencer-Martins, \& A. Fonseca. 2010. Assessment of phylloplane yeasts on selected Mediterranean plants by FISH with group- and species-specific oligonucleotide probes. FEMS Microbiol Ecol. 71: 61-72.

Istifadah, N \& T. Suganda. 2010. Influence of fungal endophytes on the health of several vegetable crops. Pp: 106-122 in Singh, KP \& D.K 
Shahi, (Eds). Microbial Diversity and Plant Disease Management for Sustainable Agriculture VDM Verlag Dr. Muller, GmbH \& Co. KG, Germany.

Istifadah, N. \& H.H. Gumelar. 2017. Potensi Bakteri Endofit Asal Daun Tomat dan Alang-Alang Untuk Menekan Penyakit Embun Tepung (Oidium Sp.) pada Tanaman Tomat. Proseding Seminar Nasional PFI Komda Yogya Solo Semarang : 370-376.

Istifadah, N. dan A.P. Cahyani. 2007. Kemampuan Jamur Endofit Akar Cabai untuk Menekan penyakit rebah Semai (Rhizoctonia solani Kuhn) pada Cabai. Proseding Seminar Nasional Perhimpunan Agronomi Indonesia (Peragi): 277-280.

Jacob D., D.R David, Y. Elad. 2007. Biology and biological control of tomato powdery mildew (Oidium neolycopersici). IOBC/wprs Bulletin, 30 (6): 329-332.

Kalogiannis S. , S.E. Tjamos, A. Stergiou, P.P. Antoniou, B.N. Ziogas, \& E.C. Tjamos. 2006. Selection and evaluation of phyllosphere yeasts as biocontrol agents against greymould of tomato. Eur J Plant Pathol., 116: 69-76.

Naidu, Y., S. Meon, Y. Siddiqui. In vitro and in vivo evaluation of microbial enriched compost tea on the development of powdery mildew on melon. Biocontrol. DOI 10.1007/s10526-0129454-2

Pretscher J, T. Fischkal, S. Branscheidt, L. Jäger, S. Kahl, M. Schlander, E. Thines \& H. Claus. 2018. Yeasts from Different Habitats and Their Potential as Biocontrol Agents. Fermentation. 4 (31); doi:10.3390/fermentation4020031.

Pretscher J., T. Fischkal, S. Branscheidt, L. Jäger, S. Kahl, M. Schlander, E. Thines \& H. Claus. 2018. Yeasts from different habitats and their potential as biocontrol agents. Fermentation. 4, 31; doi:10.3390/fermentation4020031

Punlerdmatee, B., R. Cheewangkoon \& To-anun, C. 2017. Controlling dahlia powdery mildew disease using antagonistic yeasts. Int J Agric Tech. 13:1-17.

Segarra G, M. Reis, E. Casanova, M.I. Trillas. 2009. Control of powdery mildew (Erysiphe polygoni) in tomato by foliar applications of compost tea. J. Plant Pathol. 91:683-689

Semangun, M.T. 2007. Penyakit-Penyakit Tanaman Hortikultura di Indonesia. Edisi Kedua. Gajah Mada University Press. Yogyakarta.

Zamir K. Punja, Z.K and R.S. Utkhede. 2003. Using fungi and yeasts to manage vegetable crop diseases. Trends in Biotechnol. 21: 400-407

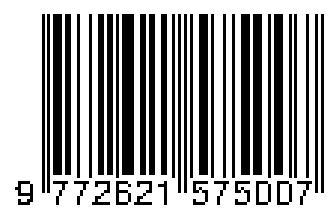

